\title{
School Environment Assisted Inside Outside Circle Learning Model on Students' Knowledge Competency of Science
}

\author{
*Ni Made Dwi Ayu Astari1, I Ketut Ardana ${ }^{2}$ \\ 1,2Program Studi Pendidikan Guru Sekolah Dasar, Universitas Pendidikan Ganesha, Singaraja, Indonesia
}

\author{
A R T I C L E I N F O \\ Article history: \\ 1 Mei 2020 Received in \\ revised form \\ 11 Juni 2020 \\ Accepted 10 Juli 2020 \\ Available online 25 Agustus \\ 2020 \\ Kata Kunci: \\ IOC, lingkungan, kompetensi \\ pengetahuan IPA \\ Keywords: \\ IOC, environment, \\ knowledge science
}

\begin{abstract}
A B S T R A K
Rendahnya kompetensi pengetahuan IPA yang dimiliki siswa yang disebabkan oleh kurang optimalnya penggunaan model saat pembelajaran menyebabkan siswa sulit untuk memahami pembelajaran. Penelitian ini bertujuan untuk mengkaji pengaruh model pembelajaran Inside Outside Circle Berbantuan Lingkungan Sekolah terhadap kompetensi pengetahuan IPA siswa kelas IV SD. Penelitian ini merupakan penelitian eksperimen semu dengan desain penelitian nonequivalent control group design. Populasi penelitian ini berjumlah 275 siswa dan sampel penelitian ditentukan menggunakan teknik random sampling. Pengumpulan data menggunakan metode tes dengan instrumen berbentuk tes pilihan ganda biasa sehingga didapatkan data berupa nilai kompetensi pengetahuan IPA yang berbentuk data kuantitatif yang dianalisis menggunakan uji-t yaitu polled varians. Hasil perhitungan data memperoleh thitung $=6,599>$ tabel $=2,000$ pada taraf
\end{abstract} signifikansi $5 \%(\mathrm{dk}=30+31-2=59)$ maka $\mathrm{H}_{0}$ ditolak dan $\mathrm{H}_{\mathrm{a}}$ diterima. Sehingga dapat disimpulkan bahwa terdapat pengaruh model pembelajaran Inside Outside Circle berbantuan lingkungan sekolah terhadap kompetensi pengetahuan IPA siswa kelas IV SD.

\section{A B S T R A C T}

The low competency of students' science knowledge due to the lack of optimal model use in learning makes students difficult to understand learning. This study aimed to determine the effect of School Environment assisted Inside Outside Circle learning model on the science knowledge competency of the fourth-grade students. This study was a quasi-experimental study with a non-equivalent control group design. The population of this study was 275 students and the study sample were determined using random sampling techniques. Data collection was applied test method with instruments in the form of ordinary multiple-choice tests so the obtained data in the form of science competency values in the form of quantitative data were analyzed using t-test, namely polled variance. The results of the data calculation were $t$ count $=6,599>t$ table $=2,000$ at a significance level of $5 \%(d k=30+31-2=59)$ then $\mathrm{H}_{0}$ was rejected and $\mathrm{H}_{\mathrm{a}}$ was accepted, which means there is an influence of School Environment assisted Inside Outside Circle learning model on the science knowledge competency of the fourth grade students.

\section{Introduction}

The efforts to create people with character and better change needs qualified education. Nowadays, qualified education is the desire of every human being. Therefore, it is necessary to develop the quality of education to create qualified human resources in the current millennial era. The development of education quality towards good change can be done by implementing the curriculum as a reference in carrying out educational programs (Pittariawati, 2020; Subawa, 2018) . In Indonesia, the 2013 curriculum has been implemented in 2013 for schools/Islamic school at this time. The curriculum 
certainly contains programs and learning objectives to be achieved, one of which is the science learning content.

Science is a study that includes inseparable aspects, the first is the product, the second is the process and the third is attitude. The science process creates knowledge which is a product of science and the product becomes the object of the study so that it passes through the stages and processes of science and it can produce new knowledge, namely products. The passed process is a science process. Tend to have an attitude which underlies Science attitude is the manifestation of Science as an attitude. The goal of science learning can be achieved if students are always active to obtain their own knowledge through the scientific process (Handayani, 2018; Winangun, 2020). Natural science learning which is done in elementary schools should go through a process that gives students real opportunities to learn. According to Piaget's theory, elementary school students are included in the concrete operational phase because in this phase students are considered to make logical reasoning for concrete things but students have not been able to reason abstract things (Ardianti et al., 2019; Khaulani et al., 2020). Therefore, students need to be learned in real terms in their learning activities.

However, in reality, many elementary school students have difficulty in learning science because they tend to memorize concepts or theories only. Learning activities in the form of memorizing theories are difficult for elementary school students due to student characteristics who like to learn in real terms, not in the form of understanding material (Ardianti et al., 2019). The results of the observation showed that the Science Middle Semester Assessment (PTS) score was 159 or $57.8 \%$ of the 275 students who had not obtained the KKM (minimum score) score, while $42.2 \%$, namely 116 students, had obtained the KKM score. This means that most students still get below score of predetermined KKM. In addition to the value of the Middle Semester Assessment (PTS) of students who have not been able to meet the KKM, the implementation of science learning activities has not fully enabled students to develop mastery of competency because the learning process in class is conducted abstractly without directly linking the facts to the real life of students. The students' problems were less active and tend to be bored with learning activities so that low student participation was also found during observation. Learning was conducted to memorize and have limited books, it also causes students to get bored because of the lack of interesting learning resources. However, learning should be meaningful where students connect information or new subject matter with concepts or other things that already exist in their cognitive structure so they can be applied to the students' daily lives (C. Dewi, 2017; Purwanto \& Aminah, 2020).

These findings are in line with a study conducted by (Desstya, 2018) which states that the consideration for teaching science in elementary school is a learning resource, which can be in the form of books, the environment, media, or others. It means that learning resources are not only linked to books. Science provides an opportunity for teachers to use something in their environment so that they can better visualize the concepts to be conveyed. The problems can be from students and teacher side (Ansori et al., 2020). Therefore, fun, active, and interesting learning is needed for students to achieve predetermined learning goals. (Sabardila et al., 2020) state that the role of the teacher is influential in the learning process through choosing the right learning model with the material being taught because a model is not necessarily suitable for every different subject. It means that the choice of the learning model greatly influences the learning atmosphere in the classroom because it will affect the competency of students' science knowledge.

In order to make the teaching and learning atmosphere more active, teacher skills are needed to motivate students to learn, namely by packaging learning materials attractively and avoid monotonous ways so that learning is not limited to transfer knowledge from teachers to students (Hariawan, 2020). If the described problems are not handled immediately, it will cause other problems and will certainly affect teaching and learning activities in the classroom. For this reason, especially teachers who teach in elementary schools should understand the basics and concepts of science learning well so that in understanding the material, students do not have difficulties or experience learning obstacles in each learning implementation (Mahdalena \& Sain, 2020). Various efforts can be made by the teacher to make it easier for students to learn, including applying a learning model. Teachers can apply learning models when learning activities take place. (Yamin \& Karmila, 2019) state that science is a study whose learning emphasizes providing direct experience to develop competencies to explore and understand the natural surroundings scientifically and to remember students in elementary schools who like to be taught with a group system so the right solution is to make the learning atmosphere interesting and encourage students. Therefore, a solution is needed for an innovative learning model. Various learning models that can be applied include the Inside Outside Circle model.

The inside outside circle learning model was first introduced by Spencer Kagan in 1993. (Pittariawati, 2020) argues that the inside outside circle learning model is a model where students share information at the same time with different partners in a short and orderly manner. The Inside Outside 
Circle model is a model that uses small and large circles where students get information directly at one time (Dewi et al., 2020). The Inside Outside Circle learning model, abbreviated as IOC, is a fun model in the teaching process so it can foster a conducive and active situation in the learning process (Devi et al., 2019; Yuliana et al., 2018). Therefore, using the Inside Outside Circle learning model can create interactive communication between fellow students or with teachers because it focuses on students to seek knowledge independently and access information as well as process information (Ilhami et al., 2020). The advantage of this model is that it has a clear structure and allows students to share information together in a short and orderly manner. In addition, this model allows students to practice communication skills. Students will understand better after sharing information with their peers (Yuliana et al., 2018). The stages of the Inside Outside Circle model are 1) the preliminary stage which includes learning preparation; 2) the core activity stage which includes the implementation of the learning model; 3) the closing stage which includes closing learning activities. The use of The Inside Outside Circle model in the teaching and learning process is assisted by using appropriate and interesting media (Sumantri, 2015; Wahyudi \& Marwiyanti, 2017).

Learning media can be used by teachers to deliver learning material so that students can easily get and understand learning material (Irwandi, 2020). Learning media also supports student learning to be more interesting and fun. The media that can be used to complement the inside outside circle learning model is the use of the school environment. The school environment is a medium that is easy to get because it is in the school environment where students study (Hodijah, 2019). Utilization of the school environment makes passive students explore more knowledge in the school environment so that the obtained material becomes meaningful for students because it provides direct experience to students in their learning. This is in line with (Oktavidola's, 2020) that the school environment is able to make learning more useful because children are faced with real and natural situations, and conditions.

Theoretically, the school environment assisted the Inside Outside Circle model has a positive effect on students' competency in science knowledge. It is supported by research a study conducted by (Budiartini et al., 2019) stated that student learning outcomes are influenced by portfolio assessment assisted Inside Outside Circle model. In addition, a study on the environment and competency of students' science knowledge has also been conducted by (Putri et al., 2019) stated that the competency of science knowledge is influenced by the environment assisted discovery learning model and the application of the Inside Outside Circle model affects student learning outcomes (Sigmarlatu et al., 2019). So, the Inside Outside Circle model and the environment has a positive effect on learning outcomes.

Based on the concept description of the Outside Circle model and the environment as well as the previous study, they become the reason for the present study aimed at examining the effect of the School Environment Assisted Inside Outside Circle learning model on the competency of science knowledge of the fifth grade elementary school students. This present study is different from the previous study. It can be seen from the material, the measured variables, the location of the study, and the research subject. The choice of this model has been adjusted to the characteristics of students and the student learning environment. In addition, this study utilized the environment around students for student learning media. It strengthened students' memory longer because students learn through their daily environment. There are several steps of The Inside Outside Circle learning, namely 1) the teacher conveys the learning objectives, conditions the class, forms a heterogeneous learning group of 4-5 people; 2) the teacher invites students to study outside the room by forming groups of students into large circles; 3) students are given problems and students solve problems with their groups with the help of the surrounding environment; 4) students convey the results of their discussions by speaking well and clearly; and 5) students are given an evaluation by the teacher individually (Ningsih \& Andriani, 2017).

\section{Method}

This present study was an experimental study with quasi-experimental which is caused by attempts to reveal a cause and effect relationship. In this present study, it was not possible to control all existing variables so this study applied a research design, namely the Non-Equivalent Control Group Design.

The population of this study was all the fourth-grade elementary school students in Cluster VI Sukawati in Academic Year 2019/2020 which consisted of 9 classes of 275 students. The determination of the research sample was conducted if the research population had been determined. The determination of the research sample applied random sampling technique. This technique was a method of determining samples with equal opportunity for all members of the population to be taken as sample 
members (Sugiyono, 2019). After determining the sample using the technique, it was found that 2 classes were selected to be the research sample, namely the sixth grade A of Elementary School (SDN) Number 6 Batubulan was selected as the experimental group and the fourth grade of Elementary School (SDN) Number 7 Batubulan was selected as the control group. The pretest was given to both research groups to equalize the research group. It is in line with (Sari et al., 2018) which state that the pretest is given to obtain the competency value of science knowledge as the benchmark in group equalization.

In this study, the collected data was students' science knowledge competency data. The data collection was done by test method. Tests are described measurements in numbers, scales, and categorical systems regarding objective behavior (Yusuf, 2015). In this study, the test was an ordinary multiple-choice test. In multiple-choice tests, it usually provides alternative possible answers, namely a, b, c, or d (Arikunto, 2018). The student who answered correctly the test item got a score of 1 and the student who answered incorrectly the test item got a score of 0 . The multiple-choice test was arranged based on the question grid that contained KD and indicators. The following is a grid of the fifth grade on science knowledge competency tests.

Table 1. The Grid of Science Knowledge Competency Tests

\begin{tabular}{|c|c|c|}
\hline Basic Competency & & Indicators \\
\hline \multirow{10}{*}{$\begin{array}{l}\text { 3.2 Comparing the life cycles of } \\
\text { several types of living things } \\
\text { and linking them with } \\
\text { conservation efforts. }\end{array}$} & 3.2 .1 & Defining the meaning of the animal life cycle \\
\hline & 3.2 .2 & $\begin{array}{l}\text { Defining the meaning of perfect and imperfect } \\
\text { metamorphosis }\end{array}$ \\
\hline & 3.2 .3 & $\begin{array}{l}\text { Determining animals' life cycle with or without } \\
\text { metamorphosis }\end{array}$ \\
\hline & 3.2 .4 & $\begin{array}{l}\text { Classifying animals that undergo complete and } \\
\text { imperfect metamorphosis }\end{array}$ \\
\hline & 3.2 .5 & $\begin{array}{l}\text { Analyzing the life cycle of several animals which } \\
\text { undergo complete and imperfect metamorphosis }\end{array}$ \\
\hline & 3.2 .6 & Determining natural resources by type \\
\hline & 3.2 .7 & $\begin{array}{l}\text { Describing the benefits of living things for humans and } \\
\text { the environment }\end{array}$ \\
\hline & 3.2 .8 & $\begin{array}{l}\text { Explaining the purpose of preserving living things in the } \\
\text { environment }\end{array}$ \\
\hline & 3.2 .9 & $\begin{array}{l}\text { Describing efforts to conserve animals and plants which } \\
\text { are living natural resources }\end{array}$ \\
\hline & 3.2 .10 & $\begin{array}{l}\text { Providing an example of the adverse effects when } \\
\text { animals and plants are overused }\end{array}$ \\
\hline
\end{tabular}

The presented test grid table had been tested for test item so that a valid science knowledge competency test was obtained with a biserial point correlation test from 40 questions. From the difference power test, it was obtained that 5 items were categorized as sufficient, 29 items were in good category and 6 items were categorized as very good. From the difficulty level test, it was obtained 10 items in the difficult category, 20 items in the medium category and 10 items in the easy category and the reliability test using KR-20 was obtained that questions on the competency of science knowledge were reliable.

The data analysis method was the inferential statistical analysis method with the t-test. Before the t-test was conducted, the prerequisite test was conducted, namely the normality test and the homogeneity test. The Kolmogorov-Smirnov analysis was used to calculate the normality of the data and Fisher's test was used for the homogeneity test in this study. The data normality test criteria were $\mathrm{D}_{\text {count }}$ $<D_{\text {table }}$ Kolmogorov Smirnov means the data is normally distributed and the criteria for the homogeneity test if $\mathrm{F}_{\text {count }}<\mathrm{F}_{\text {table }}$ means homogeneous so that the hypothesis test is the mean difference test using parametric statistics. The calculation of data analysis in this study applied Microsoft Excel 2013.

\section{Result and Discussion}

Based on the research objectives, the implementation of the study was conducted on the research sample, namely the experimental group of the fourth grade elementary school number 6 Batubulan was given treatment in the form of the school environment assisted Inside Outside Circle model and the 
fourth grade elementary school number 7 Batubulan became the control group in learning with conventional way. Each class was given 6 treatments and after that it was given a post-test in order to get the score data from each sample. Based on the calculations, the data of the two research groups were described as follows.

Table 2. The Data Description of Science Knowledge Competency

\begin{tabular}{ccc}
\hline Data Description & Experimental Group & Control Group \\
\hline $\mathrm{N}$ & 30 & 31 \\
Mean & 87,633 & 74,968 \\
Standard Deviation & 7,985 & 7,064 \\
Variance & 63,757 & 49,899 \\
\hline
\end{tabular}

Based on Table 2, the mean value of the experimental group was 87.633 and the control group was 74.968. It means that the experimental group has a higher average value than the control group. Furthermore, based on the results of the post-test, a relative frequency distribution table of the students' competency of science knowledge was compiled as follows.

Table 3. The Relative Frequency Distribution of Science Knowledge Competencies in Experiment Group Students

\begin{tabular}{ccc}
\hline $\mathbf{X}$ & $\mathbf{F}$ & $\mathbf{F r} \mathbf{( \% )}$ \\
\hline 70 & 1 & $3 \%$ \\
73 & 2 & $7 \%$ \\
75 & 1 & $3 \%$ \\
78 & 1 & $3 \%$ \\
80 & 2 & $7 \%$ \\
83 & 2 & $7 \%$ \\
85 & 2 & $7 \%$ \\
88 & 2 & $7 \%$ \\
90 & 5 & $16 \%$ \\
93 & 4 & $13 \%$ \\
95 & 6 & $20 \%$ \\
98 & 2 & $\mathbf{7 \%}$ \\
\hline Total & $\mathbf{3 0}$ & $\mathbf{1 0 0 \%}$ \\
\hline
\end{tabular}

In table 3. The relative frequency distribution table for the experimental group showed that students who were able to obtain KKM score of 75 are $90 \%$. It means that only $10 \%$ of students had not received the KKM score and most of the students, namely $90 \%$ had succeeded in achieving the KKM score. The table of the relative frequency distribution of science knowledge competencies in the control group was presented as follows.

Table 4. The Relative Frequency Distribution of Science Knowledge Competency in Control Group

\begin{tabular}{ccc}
\hline $\mathbf{X}$ & $\mathbf{F}$ & $\mathbf{F r} \mathbf{( \% )}$ \\
\hline 65 & 3 & $10 \%$ \\
68 & 4 & $13 \%$ \\
70 & 6 & $19 \%$ \\
73 & 3 & $10 \%$ \\
78 & 7 & $22 \%$ \\
80 & 4 & $13 \%$ \\
88 & 4 & $13 \%$ \\
\hline Total & $\mathbf{3 1}$ & $\mathbf{1 0 0 \%}$ \\
\hline
\end{tabular}

In table 4, the relative frequency distribution table for the science knowledge competency of the control group showed that students in the control group were able to achieve the KKM score of 75, which was $48 \%$ of all students. Around $52 \%$ of students had not been able to get KKM scores. It means that students who had not been able to obtain KKM scores were more than $52 \%$ of students. 
Before the t-test was conducted, it must pass the first prerequisite test stage, namely the normality test. Based on the calculations made in the experimental group, the value of $\mathrm{D}_{\text {count }}=0.150$ at a significant level of $5 \%$ and $\mathrm{dk} 30$ so that the value of $\mathrm{D}_{\text {table }}=0.242$. The results of $\mathrm{D}_{\text {count }}$ were then compared with $\mathrm{D}_{\text {table }}$ It can be seen that $\mathrm{D}_{\text {count }}<\mathrm{D}_{\text {table }}(0.150<0.242)$ means that the science knowledge competency data of the experimental group students are normally distributed. In the control group, the results of the normality test were obtained a value of $\mathrm{D}_{\text {count }}=0.192$ then compared with $\mathrm{D}_{\text {table }}=0.238$ with a significance level of $5 \%$ and $\mathrm{dk} 31$. It can be seen that $\mathrm{D}_{\text {count }}<\mathrm{D}_{\text {table }}(0.192<0.238)$ means that the science knowledge competency data in the control class is normally distributed. In order to show the difference in the hypothesis test, it is true because the variance between groups is different, not because of the differences within the group, a homogeneity test was conducted using the F-test. Based on the calculations, the largest variance was obtained, namely 63.757 divided by the smallest variance of 49.899 so that the $\mathrm{F}_{\text {count }}=1.28$ was obtained. These results were then compared with $\mathrm{F}_{\text {table in }}$ the numerator dk 29, namely $\left(\mathrm{n}_{1}-1\right)=(30-1)$ and dk denominator 30 , namely $\left(\mathrm{n}_{2}-1\right)=(31-1)$ at a significant level of $5 \%$ so that $F_{\text {table }}=1.85$. Because the value of $F_{\text {count }}<F_{\text {table }}(1.28<1.85)$ means that the variance of students' science knowledge competency data in the experimental group and the control group is homogeneous.

Based on the analysis results of the prerequisite hypothesis test, it was found that the competency data for the science knowledge of the experimental group and the control group were normal and homogeneous so that the t-test of the research hypothesis could be tested. Hypothesis testing was performed using t-test statistics using a polled variance. Hypothesis testing criteria were if $t_{\text {count }} \leq t_{\text {table, }}$ it means that $H_{o}$ is accepted and $H_{a}$ is rejected, and if $t_{\text {count }}>t_{\text {table }}$ means that $H_{o}$ is rejected and $\mathrm{H}_{\mathrm{a}}$ is accepted at the $5 \%$ significance level and $\mathrm{dk}=\mathrm{n}_{1}+\mathrm{n}_{2}-2$. The recapitulation of $\mathrm{t}$-test analysis of posttest data was presented in the following table

Table 5. The T-Test Analysis Recapitulation of Post-test

\begin{tabular}{ccccccccc}
\hline No & Sample & Average & Variance & $\mathbf{D k}$ & $\mathbf{N}$ & $\mathbf{t}_{\text {count }}$ & $\mathbf{t}_{\text {table }}$ & Summary \\
\hline 1 & Experimental Group & 87,633 & 63,757 & 59 & 30 & \multirow{2}{*}{6,599} & 2,000 & $\begin{array}{c}\mathrm{H}_{\mathrm{o}} \text { is } \\
\text { rejected }\end{array}$ \\
\hline
\end{tabular}

Based on the conducted hypothesis test, the value of $t=6,599$ and the value of $t$ table $=2,000$ with a significance level of $5 \%$ and $d k$ of 59 . Therefore, $t_{\text {count }}>t_{\text {table }}$ so $\mathrm{H}_{\mathrm{o}}$ was rejected and $\mathrm{H}_{\mathrm{a}}$ was accepted. It can be said that there was a significant Science Knowledge Competency among group taught using school environment assisted Inside Outside Circle learning model with groups that were taught through conventional learning in the fifth-grade elementary school. It means that there is an influence of School Environment assisted Inside Outside Circle Learning Model on the Science Competencies of the Fourth Grade Elementary School Students.

The Acquisition of data calculations showed that the average value of students whose learning activities were supported by school environment assisted Inside Outside Circle Learning Model (= 87.633) and the average value of students who were taught conventionally $(=74.968)$ so that they have a difference of 12.665. It means that the School Environment assisted Inside Outside Circle model affects the competency of students' science knowledge. The two research samples have different student knowledge competency values because learning with the School Environment Assisted Inside Outside Circle is able to activate students while learning and create interactions between students that make students more expressive in conveying the knowledge they have.

Based on the obtained findings obtained, learning with school environment assisted Inside Outside Circle model for the experimental group got positive results. It is inseparable from the steps of the school environment assisted Inside Outside Circle model that creates an active and student-centered learning atmosphere. There are several steps in conducting Inside Outside Circle according to (Ningsih \& Andriani, 2017), as follows. (1) The teacher divides students into groups of 3-4 people. (2) Each group gets the task of finding information based on the division of tasks from the teacher. (3) Each group learns independently, looking for information based on the assigned assignment. (4) After finishing it, all students mingled (not based on groups. (5) Half of the class then stand in a small circle. (6) The other half of the class form a circle instead of the first circle, facing in. (7) Two students who pairs of small and large circles share information. (8) Then, the students in the small circle stay in place, while the students who are in the large circle shift one or two steps clockwise. (9) Now, it is the turn for students to be in the large circle of sharing information. And so on, until all students have finished sharing information. 
(10) The movement is only stopped when members of the inner and outer circle groups as original pairs meet again. (11) The teacher provides evaluation or independent question exercises. From the learning step, students are able to find and compile their own knowledge independently so that students will better understand the material concept. It is supported by previous study conducted by (Ningsih \& Andriani, 2017) which states that the implementation of Inside Outside Circle model has increased students' motivation and science concepts understanding. In addition (Ningsih \& Andriani, 2017), the Inside Outside Circle model can provide many opportunities for students to process information and improve understanding of their initial concepts.

The implementation of school environment assisted Inside Outside Circle model can foster a pleasant atmosphere that will affect the learning process in pleasant conditions, students will more easily accept and find the concept being learned. It is in line with the opinion of (Devi et al., 2019) that the Inside Outside Circle learning model is a fun model to be applied in the teaching process so that it can foster a conducive and active situation in the learning process. The advantage of this model is that it has a clear structure and allows students to share information together in a short and orderly manner. In addition, this model allows students to practice communication skills. Students will understand better during sharing information with their peers (Yuliana et al., 2018). The learning structure applied in the classroom is structured and clear, it allows students to share information with different partners in a short and orderly manner. Thus, from the explanation above, it is assumed that the Inside Outside Circle learning model can improve students' science concept skills.

Inside Outside Circle model can be supported with the right media. Media that can be used to complement the Inside Outside Circle learning model is the use of the school environment. Utilization of the school environment makes passive students explore more knowledge in the school environment so that the obtained material becomes meaningful for students because it provides direct experience to students in their learning. It is supported by (Oktavidola's research, 2020) which states that the school environment is able to make learning more useful because children are faced with real and natural situations and conditions. School environment assisted Inside Outside Circle model to the experimental group is able to overcome student difficulties in learning both problems from inside the student and outside the student. This model emphasizes fun group learning for students to obtain information about the material being learned. Students will not feel bored and find it easier to understand learning. It will not be in the form of memorizing theory alone because students are directly faced with the school environment which will find out the cause and effect of the obtained material.

The results of this study are supported by a study conducted by (Muyaroah, 2018) which states that the effectiveness of the Inside Outside Circle learning model on science learning outcomes and (Budiartini et al., 2019) state that student learning outcomes are influenced by portfolio assessment assisted Inside Outside Circle model. In addition, research on the environment and competency of students' science knowledge has also been conducted by (Putri et al., 2019) state that the competency of science knowledge is influenced by the environment assisted discovery learning model and the application of the Inside Outside Circle model affects student learning outcomes (Sigmarlatu et al., 2019). The implementation of school environment assisted Inside Outside Circle model has a positive effect on students' competency in science. In this study, the difference from the previous study can be seen the media that is a concrete daily environment, it helps to strengthen students' memory longer. It is because students learn through their own experiences socializing with the surrounding environment.

Based on the previous description, it can be said that the school environment assisted Inside Outside Circle model affects the science knowledge competency of elementary school students. Thus, this study proves that the school environment assisted Inside Outside Circle model is good to be applied during learning, especially on science lessons. The benefit of applying school environment assisted Inside Outside Circle model, namely students involve directly with the real school environment so that students are able to further explore their knowledge which is not limited to memorize theories and students will understand the material being learned longer. In addition, the application of this model makes student interaction better because students will share information with their friends together which makes the atmosphere of mutual cooperation tighter.

\section{Conclusion}

Based on data analysis and discussion, there is a significant difference in Science Knowledge Competency between the groups that are taught with school environment assisted Inside Outside Circle model and the groups that are taught through conventional learning in the fifth-grade elementary school. It means that there is a significant effect of the school environment assisted Inside Outside Circle model on the science knowledge competency of the fifth-grade elementary school students. 


\section{References}

Ansori, I., Jaelani, A. K., \& Affandi L. Hamdian. (2020). Pengaruh Model Contextual Teaching And Learning dengan Media Video Pembelajaran Terhadap Hasil Belajar IPA Siswa Kelas V SDN 9 Ampenan Tahun Pelajaran 2019/2020. 1(1),33-41. http://prospek.unram.ac.id/index.php/PROSPEK/index

Ardianti, S. D., Wanabuliandari, S., Rahardjo, S., \& Kudus, U. M. (2019). The Implementation of E-Jas Science Edutainment To Improve Elementary School Student ' S Conceptual Understanding. Unnes Science Education Journal, 8(1), 1-6. https://doi.org/10.15294/usej.v8i1.28387

Arikunto, S. (2018). Dasar-Dasar Evaluasi Pendidikan. Bumi Aksara.

Budiartini, N. N., Pudjawan, K., \& Parmiti, D. P. (2019). Pengaruh Model Pembelajaran Inside Outside Circle Berbantuan Asesmen Portofolio Terhadap Hasil Belajar IPA. Jurnal Pedagogi Dan Pembelajaran, 1(2), 103. https://doi.org/10.23887/jp2.v1i2.19337

Desstya, A. (2018). Joyfull Learning In Science ( Pelatihan Percobaan Ipa Sederhana Di SD Bener I Dan Bener II ). University Research Colloquium, 2(1), 51-56.

Devi, P. I. S., Putra, M., \& Putra, D. K. N. S. (2019). Pengaruh Model Pembelajaran Inside Outside Circle Berbantuan Comic Card Terhadap Kompotensi Pengetahuan IPS Kelas V. Media Komunikasi FPIPS, 17(2), 100-109. https://doi.org/10.23887/mkfis.v17i2.22230

Dewi, C. (2017). Peningkatan Keterampilan Berbicara Dalam Bermain Drama Melalui Model Pembelajaran Kooperatif Tipe Inside-Outside Circle. JINoP (Jurnal Inovasi Pembelajaran), 3(2), 567. https://doi.org/10.22219/jinop.v3i2.4575

Dewi, S. S., Uswatun, D. A., \& Sutisnawati, A. (2020). Penerapan Model Inside Outside Circle Untuk Meningkatkan Keterampilan Komunikasi Siswa Dalam Pembelajaran IPA di Kelas Tinggi. Jurnal Utile, 6(1), 86-91. https://doi.org/10.37150/jut.v6i1.720

Handayani, T. (2018). Peningkatan Pemahaman Konsep IPA Menggunakan Model Pembelajaran Inkuiri Terbimbing di SD. Edutainment, 6(2), 130-153. https://doi.org/10.35438/e.v6i2.94

Hariawan, I. K. (2020). Penerapan Model Pembelajaran Grup Investigation (GI) Berbantuan Vidio Pembelajaran Untuk Meningkatkan Hasil Belajar IPA. Cetta: Jurnal Ilmu Pendidikan, 3(1), 1-16. https://doi.org/10.37329/cetta.v3i1.406

Hodijah, A. S. (2019). Meningkatkan Kemampuan Menulis Karangan Deskripsi dengan Pemanfaatan Lingkungan Sekolah. Dinamika: Jurnal Bahasa, Sastra Dan Pengajarannya, 2(1), 90-97.

Ilhami, B. S., Husni, M., Ramdhani, S., Uyun, N., Ilmu, F., \& Universitas, P. (2020). Inside Outside Cyrcle: Metode Pembelajaran Untuk Mengembangkan Kemampuan Berbicara Anak. Jurnal Pelita PAUD, 4(2), 247-253. https://doi.org/10.33222/pelitapaud.v4i2.1001

Irwandi. (2020). Penggunaan Media Audio Visual Dalam Peningkatan Hasil Belajar Materi Rukun Iman Pada Siswa Kelas I SD Negeri 49 Kota Banda Aceh. Pionir Jurnal Pendidikan, 9(1), 25-44. http://dx.doi.org/10.22373/pjp.v9i1.7144

Khaulani, F., S, N., \& Irdamurni, I. (2020). Fase Dan Tugas Perkembangan Anak Sekolah Dasar. Jurnal Ilmiah Pendidikan Dasar, 7(1), 51. https://doi.org/10.30659/pendas.7.1.51-59

Mahdalena, S., \& Sain, M. (2020). Meningkatkan Hasil Belajar Siswa Melalui Penerapan Model Pembelajaran Cooperative Script Pada Mata Pelajaran Ilmu Pengetahuan Sosial Kelas VA Siswa Sekolah Dasar Negeri 010 Sungai Beringin. Asatiza Jurnal Pendidikan, 1(1), 118-138. https://doi.org/10.46963/asatiza.v1i1.63

Muyaroah, S. (2018). Efektifitas Model Pembelajaran Inside Outside Cirle Terhadap Hasil Belajar Siswa Pada Mata Pelajaran IPA SD Fransiskus Baturaja. Pedagogia, 16(2), 99. https://doi.org/10.17509/pdgia.v16i2.12052

Oktavidola, M. (2020). Efektivitas Pemanfaatan Lingkungan Sekolah dalam Meningkatkan Kemampuan Membaca Kata bagi Anak Kesulitan Belajar Kelas III di SDN 33 Kalumbuk Padang. Jurnal Penelitian Pendidikan Khusus, 8(1), 19-24. https://doi.org/10.24036/juppekhu1060170.64

Pittariawati. (2020). Penggunaan Model Pembelajaran Inside-Outside Circle Untuk Meningkatkan Pemahaman Siswa SMA Kelas XI Pada Materi Teks Prosedur. Jurnal Pendidikan Tambusai, 4(1), 
73-81. https://doi.org/10.31004/jptam.v4i1.431

Purwanto, H., \& Aminah, S. (2020). Peranan Ingatan Serta Implikasinya Dalam Proses Pembelajaran. Journal of Education Informatic Technology and Science, 2(3), 45-54. https://doi.org/10.37859/jeits.v2i3.1687

Putri, N. M. C. N. M., Ardana, I. K., \& Agustika, G. N. S. (2019). Pengaruh Model Discovery Learning Berbantuan Lingkungan Terhadap Kompetensi Pengetahuan IPA Siswa Kelas V. Mimbar PGSD, 7(2), 57-64. http://dx.doi.org/10.23887/jjpgsd.v7i2.17471

Sabardila, A., Fachri, A. R., Santoso, E., Aini, N. N., Safitri, M., Putri, D. M., Damayanti, N. A., Hermawati, L., Pratiwi, A. N., \& Safira, R. (2020). Peningkatan Antusiasme dan Pemahaman Siswa dalam PBM melalui Metode Talking Stick di MIM Jatisari Kedungdowo, Boyolali. Buletin KKN Pendidikan, 1(2), 56-62. https: //doi.org/10.23917/bkkndik.v1i2.10765

Sari, M. D. L., Suniasih, N. W., \& Suadnyana, I. N. (2018). Pengaruh Model Pembelajaran Artikulasi Menggunakan Media Booklet terhadap Kompetensi Pengetahuan IPA. Jurnal Pedagogi Dan Pembelajaran, 1(3), 154-161. https://doi.org/10.23887/mi.v23i2.16416

Sigmarlatu, R., Ritiauw, S. P., \& Mahananingtyas, E. (2019). Penerapan Model Pembelajaran Inside Outside Circle Untuk Meningkatkan Hasil Belajar Siswa Kelas V Sd Negeri 1 Latihan Spg Ambon. Jurnal Pedagogika Dan Dinamika Pendidikan, 7(1), 45-61. https://ojs3.unpatti.ac.id/index.php/pedagogika/article/view/1709

Subawa, P. (2018). Mencetak Lulusan Yang Berkarakter Dan Berkualitas. Purwadita, 2(1), 87-93.

Sugiyono. (2019). Meode Penelitian Kuantitatif Kualitatif dan R\&D (2nd ed.). Alfabeta.

Sumantri, M. S. (2015). Strategi Pembelajaran (1st ed.). Rajawali Pers.

Wahyudi, D., \& Marwiyanti, L. (2017). Penerapan Model Pembelajaran Inside Outside Circle Dalam Mata Pelajaran Akidah Akhlak. Jurnal MUDARRISUNA: Media Kajian Pendidikan Agama Islam, 7(2), 267292. https://doi.org/10.22373/jm.v7i2.2369

Winangun, I. M. A. (2020). Media Berbasis Budaya Lokal dalam Pembelajaran IPA SD. Edukasi: Jurnal Pendidikan Dasar, 65-72. https://jurnal.stahnmpukuturan.ac.id/index.php/edukasi/article/view/529

Yamin, M. R., \& Karmila. (2019). Analisis Kebutuhan Pengembangan Media Pembelajaran Berbasis Cartoon dalam Pembelajaran IPA pada Materi Lingkungan Kelas III SD. Biology Teaching and Learning, 2(2), 159-170. https://ojs.unm.ac.id/btl/article/view/12307

Yuliana, L., Barlian, I., \& Jaenuddin, R. (2018). Pengaruh Model Pembelajaran Kooperatif Tipe Inside Outside Circle terhadap Keaktifan Belajar Peserta Srijaya Negara Palembang. Jurnal Profit, 5(1), 17-27. https: //doi.org/10.36706/jp.v5i1.5633

Yusuf, M. (2015). Asessmen dan Evaluasi Pendidikan. Prenadamedia Group. 